\title{
Thermococcus thioreducens sp. nov., a novel hyperthermophilic, obligately sulfur-reducing archaeon from a deep-sea hydrothermal vent
}

Correspondence

Elena V. Pikuta

elenapikuta@hotmail.com
Elena V. Pikuta, ${ }^{1}$ Damien Marsic, ${ }^{2}$ Takashi Itoh, ${ }^{3}$ Asim K. Bej, ${ }^{4}$ Jane Tang, ${ }^{5}$ William B. Whitman, ${ }^{6}$ Joseph D. $\mathrm{Ng}^{2}$ Owen K. Garriott ${ }^{7}$ and Richard B. Hoover ${ }^{1}$

\author{
${ }^{1}$ Astrobiology Laboratory, NASA/NSSTC, VP62, 320 Sparkman Dr., Huntsville, AL 35805, USA \\ ${ }^{2}$ Laboratory for Structural Biology, Department of Biological Sciences, The University of \\ Alabama in Huntsville, MSB 221, Huntsville, AL 35899, USA \\ ${ }^{3}$ Japan Collection of Microorganisms, RIKEN BioResource Center, 2-1 Hirosawa, Wako-shi, \\ Saitama 351-0198, Japan \\ ${ }^{4}$ Department of Biology, University of Alabama at Birmingham, Birmingham, AL 35294, USA \\ ${ }^{5}$ United States Department of Agriculture, Monitoring Programs Office, 8609 Sudley Rd., \\ Suite 206, Manassas, VA 20110, USA \\ ${ }^{6}$ Department of Microbiology, University of Georgia, Athens, GA 30602-2605, USA \\ ${ }^{7}$ Department of Biological Sciences, UAH, Huntsville, AL 35899, USA
}

The genus Thermococcus was created in 1983, and currently 26 species have been validly published. All members of this genus are characterized by a thermophilic nature, anaerobiosis with sulfur-type respiration and sometimes sulfur stimulation for fermentation (Zillig, 1992; Zillig \& Reysenbach, 2002). The typical ecological systems for the habitat of Thermococcus species include geothermal springs

Abbreviation: TEM, transmission electron microscopy.

The GenBank accession number for the 16S rRNA gene sequence of strain OGL-20P' is AF394925. (volcanic fumaroles, geysers and deep-sea hydrothermal vents), deep subsurface biosphere, such as deep crustal rocks, and aquifers and high-temperature oil wells (Stetter et al., 1993; Takahata et al., 2000; Miroshnichenko et al., 2001). Most species of the genus are marine and have an optimum $\mathrm{NaCl}$ concentration for growth of about $3 \%$ $(\mathrm{w} / \mathrm{v})$, but there are also freshwater species, e.g. Thermococcus zilligii (Ronimus et al., 1997) and Thermococcus waiotapuensis (González et al., 1999). Most grow optimally at neutral or slightly acidic $\mathrm{pH}$, but only Thermococcus alcaliphilus is capable of growth at $\mathrm{pH} 10.5$ with an optimum around 9.0 (Keller et al., 1995). Most species 
have a minimum temperature for growth around $50{ }^{\circ} \mathrm{C}$ and the maximum around $95-100{ }^{\circ} \mathrm{C}$, e.g. Thermococcus celer, Thermococcus litoralis and Thermococcus fumicolans (Zillig et al., 1983; Neuner et al., 1990; Godfroy et al., 1996). Many species have been isolated from deep-sea hydrothermal vents with environmental pressures in excess of $200 \mathrm{~atm}$. Obligate dependence upon pressure at $95-100{ }^{\circ} \mathrm{C}$ has been determined for Thermococcus barophilus (Marteinsson et al., 1999). The most radio-resistant hyperthermophilic archaeon, Thermococcus gammatolerans, is capable of surviving $30 \mathrm{kGy} \gamma$-ray irradiation (Jolivet et al., 2003). Most species of the genus are sulfur-reducing organisms; however, Slobodkin et al. (1999) reported dissimilatory reduction of $\mathrm{Fe}$ (III) by Thermococcus sp. T642. In this article we describe a novel hyperthermophilic archaeon, Thermococcus thioreducens sp. nov., which is an obligate sulfur-reducer, and was isolated from the Rainbow deep-sea hydrothermal vent site in the Mid-Atlantic Ridge.

'Black smoker' chimney material samples were collected in October 1999 from $2300 \mathrm{~m}$ depth in the Rainbow hydrothermal vent field $\left(36.2^{\circ} \mathrm{N}, 33.9^{\circ} \mathrm{W}\right)$ about $800 \mathrm{~km}$ south-west of the Azores on the Azorean segment of the Mid-Atlantic Ridge. Remote manipulators (on the Mir submersible launched from the Russian oceanographic research vessel Akademik Mstislav Keldysh) were used to place the samples on a collection tray for return to the surface. After a brief exposure to the ambient atmosphere during recovery of the submersible from the water, the samples were hermetically sealed in sterile vessels with screw caps and maintained at $4{ }^{\circ} \mathrm{C}$ in an insulated cooler during transport to the Astrobiology Laboratory of the NASA Marshall Space Flight Center, Huntsville, AL, USA. Strain OGL-20 $\mathrm{P}^{\mathrm{T}}$ was isolated from a sample of black-coloured, fine-grained sand and mud (neutral $\mathrm{pH}, 3 \%$, w/v, salinity) that contained chimney debris material and organic sediments.

The enrichment, isolation and cultivation of the new isolate were performed in liquid medium under a highly purified $100 \%$ nitrogen atmosphere. The basal medium contained $\left(\mathrm{g} \mathrm{l}^{-1}\right): \mathrm{KH}_{2} \mathrm{PO}_{4}, 0.3 ; \mathrm{MgCl}_{2} .6 \mathrm{H}_{2} \mathrm{O}, 0.1 ; \mathrm{KCl}, 0.3 ; \mathrm{NH}_{4} \mathrm{Cl}$, $1.0 ; \mathrm{NaHCO}_{3}, 0.2 ; \mathrm{CaSO}_{4} .7 \mathrm{H}_{2} \mathrm{O}, 0.005 ; \mathrm{NaCl}, 30.0$; $\mathrm{Na}_{2} \mathrm{~S} .9 \mathrm{H}_{2} \mathrm{O}, 0.4$; yeast extract, 0.5 ; sulfur powder, 10.0 ; peptone, 5.0; resazurin, 0.001 . The medium was supplemented with $2 \mathrm{ml}$ vitamin solution (Wolin et al., 1963) and $1 \mathrm{ml}$ trace element solution as described previously (Pikuta et al., 2000). The final $\mathrm{pH}$ of the medium after autoclaving was $7.2-7.4$ at $22^{\circ} \mathrm{C}$.

Unless otherwise noted, enrichment and pure cultures were grown in $10 \mathrm{ml}$ medium in Hungate tubes under $100 \% \mathrm{~N}_{2}$ (1 atm). All transfers and samplings of cultures were performed with sterile syringes. The medium was sterilized at $121{ }^{\circ} \mathrm{C}$ for $60 \mathrm{~min}$ and, after adding sulfur to the tubes under flow of $100 \% \mathrm{~N}_{2}$, an additional sterilization was performed at $110^{\circ} \mathrm{C}$ for $30 \mathrm{~min}$. All incubations for physiological tests were carried out at $83^{\circ} \mathrm{C}$. One half gram of sample L-20 was injected into the medium and incubated for $24 \mathrm{~h}$. A pure culture of strain OGL-20 $\mathrm{P}^{\mathrm{T}}$ was obtained after repeated serial dilutions. A culture with monotypic morphology on the $10^{-9}$ dilution plate was chosen for roll-tube serial dilution purification. Growth of colonies occurred after 2-3 days incubation on 3\% (w/v) Difco agar with sulfur powder in Hungate tubes at $70{ }^{\circ} \mathrm{C}$. One colony from the $10^{-8}$ dilution roll tube was chosen for subsequent purification and was designated strain OGL$20 \mathrm{P}^{\mathrm{T}}$. The colonies of strain OGL-20 $\mathrm{P}^{\mathrm{T}}$ on the surface of the agar were whitish-cream in colour, glossy and shining, with a round shape $(\sim 1.5 \mathrm{~mm}$ diam. $)$ and irregular cleaved edges, and convex with a denser raised conic centre. In deep agar, colonies had a convex/convex lenticular shape.

Phase-contrast microscopy revealed the cells of strain OGL-20P $\mathrm{P}^{\mathrm{T}}$ to be irregular, motile cocci with a diameter of $0.7-1.7 \mu \mathrm{m}$. Occasionally, some of the cells appeared as diplococci or conglomerates of 10-15 cells. Transmission electron microscopy (TEM) was carried out using a JEOL TEM $100 \mathrm{CX}$ II operating at $80 \mathrm{kV}$. Negative staining was performed using a uranyl acetate procedure as described previously (Pikuta et al., 2003). TEM images showed the presence of a single flagellum (Fig. 1).

Culture growth was measured by direct cell counting under a phase-contrast microscope (Fisher Micromaster) by measuring sulfide produced from sulfur (Trüper \& Schlegel, 1964) or by estimating the increase in optical density at $595 \mathrm{~nm}$ (Genesis 5; Spectronic Instruments). The $\mathrm{pH}$ of the medium was adjusted to defined values with sterile stock solutions of $6 \mathrm{M} \mathrm{HCl}$ or $6 \mathrm{M} \mathrm{NaOH}$ under a flow of $\mathrm{N}_{2}$ and measured using a $\mathrm{pH}$ meter (model 230 Aplus; Orion) calibrated at $22^{\circ} \mathrm{C}$. All measurements were performed after cooling the culture samples to room temperature. The temperature range for growth was determined in liquid medium at $\mathrm{pH}$ 7.3. The effect of $\mathrm{NaCl}$ concentration on growth was determined in liquid medium containing $0.0,0.5,1.0,2.0$,

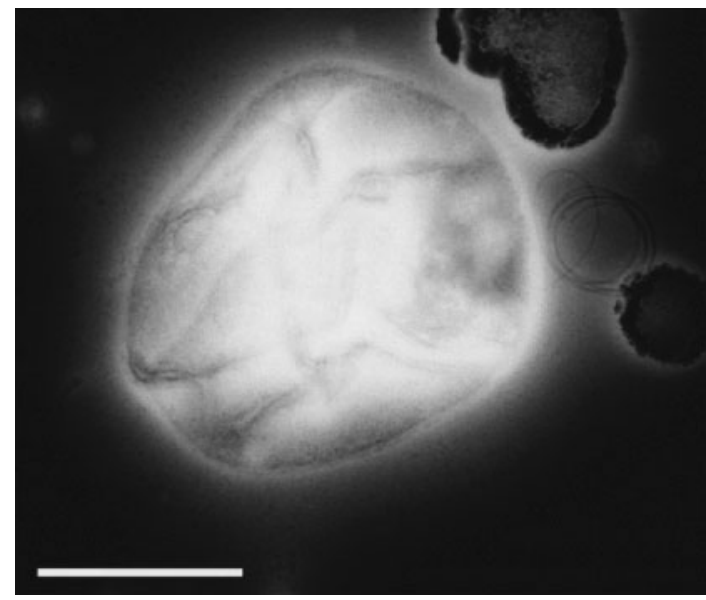

Fig. 1. TEM image of a negatively stained cell of strain OGL$20 \mathrm{P}^{\top}$ with a single coiled flagellum. Bar, $0.5 \mu \mathrm{m}$. 
3.0, 5.0, 7.0 or $10.0 \%(\mathrm{w} / \mathrm{v}) \mathrm{NaCl}$. The $\mathrm{NaCl}$ requirement was studied using a modified medium in which $\mathrm{NaHCO}_{3}$ was replaced with $\mathrm{K}_{2} \mathrm{CO}_{3}$, and $\mathrm{Na}_{2} \mathrm{~S}$ was replaced with $\mathrm{K}_{2} \mathrm{~S}$. Growth of strain OGL-20 ${ }^{\mathrm{T}}$ was observed in the temperature range $55-95^{\circ} \mathrm{C}$, with an optimum between 83 and $85^{\circ} \mathrm{C}$. It survived for $30 \mathrm{~min}$ at $101^{\circ} \mathrm{C}$, but incubation at $103^{\circ} \mathrm{C}$ for $2 \mathrm{~h}$ killed the cells. Growth of strain OGL-20P $\mathrm{P}^{\mathrm{T}}$ was observed within the $\mathrm{pH}$ range $5.0-8.5$, with an optimum $\mathrm{pH}$ of 7.0. It also grew within an $\mathrm{NaCl}$ concentration range of $1-5 \%$ with an optimum of $3 \%$. No growth was observed for $\mathrm{NaCl}$ concentrations below 0.5 or above $7 \%$. The doubling time, measured by direct cell counting under a phasecontrast microscope, for a fresh culture of OGL-20P ${ }^{\mathrm{T}}$ incubated under optimal conditions was $30 \mathrm{~min}$.

Strain OGL-20P $\mathrm{P}^{\mathrm{T}}$ was found to be strictly anaerobic. Catalase activity, which was tested as described by Smibert \& Krieg (1994), showed a negative reaction. The utilization of various electron acceptors was studied in a medium containing peptone $\left(5 \mathrm{~g} \mathrm{l}^{-1}\right)$ as electron donor. Electron acceptors were added in the form of autoclaved or filtersterilized stock solutions. The final concentrations of electron acceptors were as follows $(\mathrm{mM}): \mathrm{Na}_{2} \mathrm{SO}_{4}, 20$; $\mathrm{Na}_{2} \mathrm{SO}_{3}, 5 ; \mathrm{Na}_{2} \mathrm{~S}_{2} \mathrm{O}_{3} \cdot \mathrm{H}_{2} \mathrm{O}, 10 ; \mathrm{NaNO}_{3}, 10 ; \mathrm{Fe}(\mathrm{OH})_{3}, 100 ; \mathrm{S}^{0}$, 300. An amorphous $\mathrm{FeOOH}$ suspension (iron gel) was prepared by neutralizing a $0.4 \mathrm{M}$ solution of $\mathrm{FeCl}_{3}$ to $\mathrm{pH} 7$ by using $10 \mathrm{M} \mathrm{NaOH}$ as described by Lovley \& Phillips (1986). Only elemental sulfur was used as an electron acceptor, which resulted in the production of hydrogen sulfide (15-20 mM). No growth was observed in the absence of sulfur on all tested substrates.

The ability of strain OGL-20 $\mathrm{P}^{\mathrm{T}}$ to utilize various substrates was tested by using liquid medium supplemented with autoclaved or filter-sterilized substrates at a final concentration of $5 \mathrm{~g} \mathrm{l}^{-1}$. Substrate utilization was tested by cultivating strain OGL-20 $\mathrm{P}^{\mathrm{T}}$ for $1-6$ days on different substrates, and growth was detected under a microscope and by measurement of hydrogen sulfide. Growth was observed on proteolysis products peptone, bactotryptone, Casamino acids and yeast extract. No growth was observed in the presence of glucose, fructose, maltose, sucrose, D-mannitol, glycerol, methanol, ethanol, butyrate, propionate, acetate, formate, lactate, pyruvate, citrate and separate amino acids (L- and D-leucine, L- and D-methionine, L- and D-histidine $\mathrm{HCl}, \mathrm{L}-$ cysteine, L-proline, L-lysine, L-cystine, glycine, L-glutamine, L-alanine, L-serine, L-tyrosine, L-phenylalanine, L-valine, L-isoleucine, L-tryptophan, L-arginine).

Metabolic end products in the liquid phase were determined by HPLC. Separation was done on an Aminex HPX-87H (Bio-Rad) column with $5 \mathrm{mM} \mathrm{H}_{2} \mathrm{SO}_{4}$ as the mobile phase. Gases were measured with a gas chromatograph 3700 (Varian) equipped with a Porapak Q column and a TCD detector. Nitrogen was used as the gas carrier. Acetate $(2.1 \mathrm{mM})$ and ethanol $(3.7 \mathrm{mM})$ were detected in the liquid phase as minor end products. Hydrogen sulfide ( $>20 \mathrm{mM}$ ) and traces of hydrogen and $\mathrm{CO}_{2}$ were measured in the gas phase during growth of OGL-20P ${ }^{\mathrm{T}}$.
Antibiotic susceptibility was determined by transferring an exponentially growing culture into basal medium containing filter-sterilized antibiotics at a concentration of $100 \mu \mathrm{g} \mathrm{ml}^{-1}$ (chloramphenicol, rifampicin) or $250 \mu \mathrm{g}$ $\mathrm{ml}^{-1}$ (ampicillin, tetracycline, kanamycin and gentamicin). Before incubation at $83^{\circ} \mathrm{C}$, antibiotic-containing cultures were pre-incubated at $37^{\circ} \mathrm{C}$ for $12 \mathrm{~h}$. Strain OGL-20P $\mathrm{P}^{\mathrm{T}}$ was resistant to ampicillin, gentamicin, kanamycin and chloramphenicol (growth without changes of morphology and motility), but was sensitive to tetracycline and rifampicin.

Genomic DNA was isolated by a standard phenol/chloroform extraction followed by ethanol precipitation (Sambrook et al.,1989). The G+C content of DNA was determined by HPLC (Mesbah et al., 1989). Details of the procedure were described previously (Hoover et al., 2003). The $\mathrm{G}+\mathrm{C}$ content of the genomic DNA of strain OGL-20P ${ }^{\mathrm{T}}$ was $57.2 \pm 0.2 \mathrm{~mol} \%$ (mean of two determinations for each of two degradations of the DNA $\pm \mathrm{SD}, n=4$ ).

The $16 \mathrm{~S}$ rRNA gene of strain OGL-20P ${ }^{\mathrm{T}}$, along with part of the $23 \mathrm{~S}$ rRNA gene and the spacer region, was selectively amplified with the following primers: $5^{\prime}$-TCCGGTTGATCCTGCCGG-3' (forward) and 5' -CTTTTCCTGCGGGTACTAAG-3' (reverse). PCR was performed with $30 \mathrm{pmol}$ each primer in a $50 \mu$ volume, using 2 U ThermalAce DNA polymerase (Invitrogen) in the buffer provided. The thermal cycling profile was as follows: $3 \mathrm{~min}$ at $95^{\circ} \mathrm{C}$ initial denaturation, followed by 30 cycles of $45 \mathrm{~s}$ denaturation at $95^{\circ} \mathrm{C}$, $45 \mathrm{~s}$ annealing at $57^{\circ} \mathrm{C}$ and 4 min extension at $72^{\circ} \mathrm{C}$, with a final extension step at $72^{\circ} \mathrm{C}$ for $15 \mathrm{~min}$. The amplified fragment was extracted from a $1.5 \%$ agarose gel using the Qiaquick extraction kit (Qiagen), and then subcloned using the Zero Blunt TOPO PCR Cloning kit (Invitrogen). Six clones were sequenced in both directions using the Dye Terminator AmpliTaq FS Cycle Sequencing kit (Applied Biosystems) with both vector-based primers and primers specific to the $16 \mathrm{~S}$ internal sequence (designed by ourselves).

The 16S rRNA sequence of strain OGL-20 $\mathrm{P}^{\mathrm{T}}$ was aligned with closely related sequences found in GenBank after a BLAST search (Altschul et al., 1990), using CLUSTAL W (Thompson et al., 1994). Pairwise distances were computed with MEGA version 3.1 (Kumar et al., 2004) using the JukesCantor model (Jukes \& Cantor, 1969). An unrooted phylogenetic tree was constructed with the same MEGA program using the neighbour-joining method (Saitou \& Nei, 1987).

A sequence covering $1885 \mathrm{nt}$, including most (1452 nt) of the $16 \mathrm{~S}$ rRNA gene, the tRNA ${ }^{\mathrm{Ala}}$ gene and part of the $23 \mathrm{~S}$ rRNA gene, was obtained after amplification of strain OGL$20 \mathrm{P}^{\mathrm{T}}$ DNA. The $16 \mathrm{~S}$ rRNA gene sequence corresponded to positions 37-1496 of the Pyrococcus furiosus 16S rRNA sequence (accession no. U20163) used as a reference. A BLAST search against the GenBank database revealed a high level of similarity $(>97 \%)$ with sequences from other Thermococcus species. A phylogenetic dendrogram showing the relationship of strain OGL-20 $\mathrm{P}^{\mathrm{T}}$ to the 11 closest species 


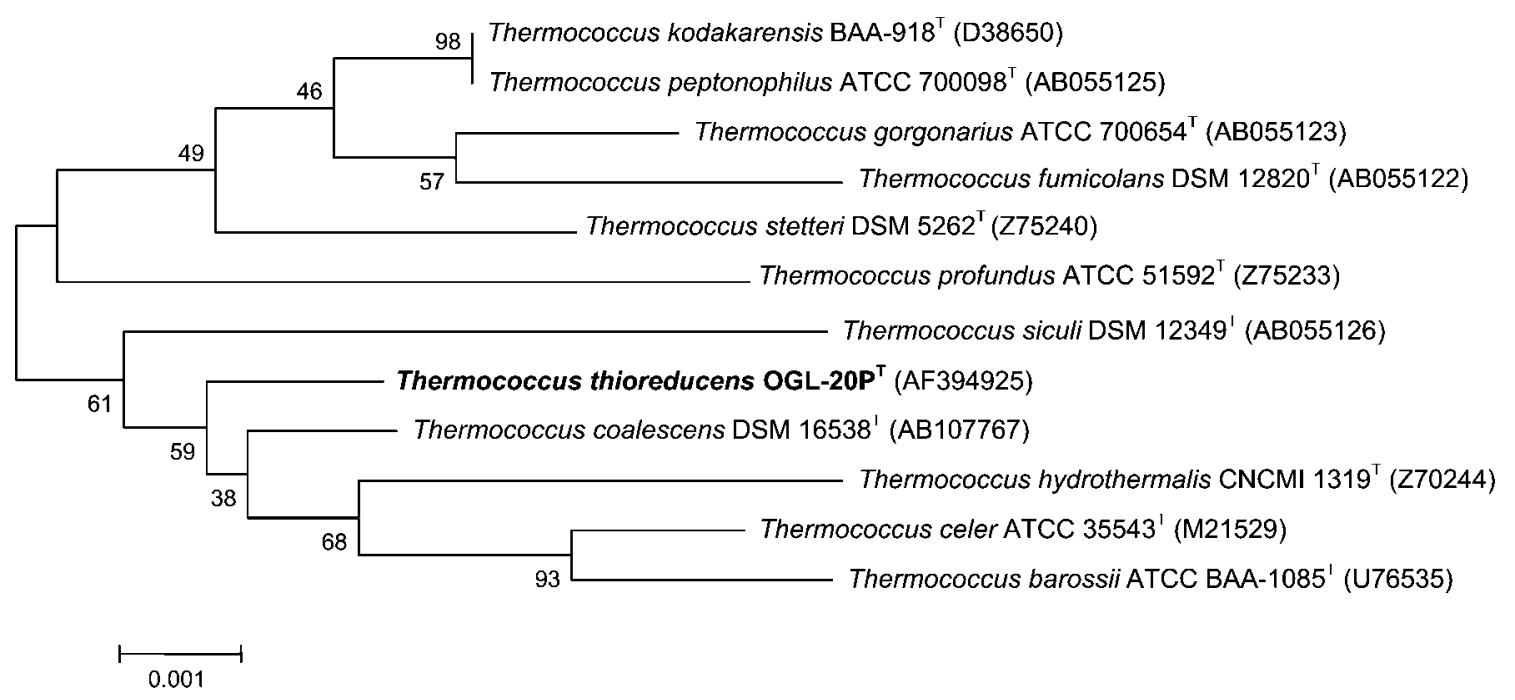

Fig. 2. Unrooted phylogenetic tree indicating the position of strain $O G L-20 P^{\top}$ among closest taxa. Numbers at the nodes are bootstrap values obtained from 1000 replicates. Nucleotide sequence accession numbers are shown in parentheses. Scale bar indicates 1 inferred nucleotide substitution per 1000 nt.

was constructed, based on 1400 common nucleotide sites

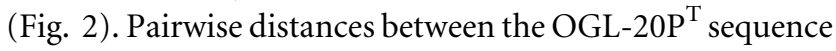
and its closest neighbours were $0.003,0.006,0.006$ and 0.007 for Thermococcus coalescens, Thermococcus celer, Thermococcus hydrothermalis and Thermococcus barossii, respectively, based on the same 1400 nucleotide sites.

Homologies of genomic DNA between the new isolate and the phylogenetically closest Thermococcus species were determined as described previously (Pikuta et al., 2006). The DNA-DNA hybridization values with labelled DNA from strain OGL-20 $\mathrm{P}^{\mathrm{T}}$ were as follows: Thermococcus celer JCM $8558^{\mathrm{T}}, 14 \%$; Thermococcus barossii ATCC BAA- $1085^{\mathrm{T}}$, $17 \%$; Thermococcus hydrothermalis AL662 ${ }^{\mathrm{T}}, 16 \%$; Thermococcus kodakarensis ATCC BAA- $918^{\mathrm{T}}, 5 \%$; Thermococcus profundus ATCC $51592^{\mathrm{T}}, 4 \%$; Thermococcus acidaminovorans DSM $11906^{\mathrm{T}}, 5 \%$; Thermococcus stetteri DSM $5262^{\mathrm{T}}$, $4 \%$; Thermococcus peptonophilus ATCC $700098^{\mathrm{T}}, 5 \%$; Thermococcus gorgonarius ATCC $700654^{\mathrm{T}}, 5 \%$; Thermococcus coalescens JCM $12540^{\mathrm{T}}$, $13 \%$; and 'Thermococcus radiotolerans' JCM 11826, $18 \%$.

Almost half of the known Thermococcus species have been isolated from deep-sea hydrothermal vents with high pressure conditions (200-350 atm) located in different parts of the world (Kobayashi et al.,1994; Huber et al.,1995; Godfroy et al., 1996, 1997; Canganella et al.,1998; Duffaud et al.,1998; Grote et al.,1999). Strain OGL-20P ${ }^{\mathrm{T}}$ was also isolated from a deep-sea ecosystem, characterized by high pressure (230 atm), localized high temperatures (300 to $400{ }^{\circ} \mathrm{C}$ within black smoker vents) and very high thermal gradients, (temperature drops to $2{ }^{\circ} \mathrm{C}$ a few centimetres away from the chimney). As the hydrothermal fluid condenses above the vent, the precipitated minerals are also spread around the nearby ocean floor; black pyrites $(\mathrm{FeS})$ surrounding black smokers is a result of the interaction of sulfide with iron and the orange colour is a result of $\mathrm{Fe}^{3+}$. Since it is a mantellic rather than a basaltic substrate, the fluid chemistry of the Rainbow site is completely original as fluids are depleted in sulfide but enriched in both methane and hydrogen (Charlou et al., 2002). Unpigmented invertebrates (shrimps, crabs and worms) represent multicellular organisms in the ecosystem; their energy source is partially provided by the metabolism of micro-organisms (in our laboratory, cells with a morphology similar to the new archaeon were found in shrimps intestines that had a strong smell of sulfur).

Strain OGL- $20 \mathrm{P}^{\mathrm{T}}$ is a hyperthermophilic, heterotrophic, sulfur-dependent, coccoid archaeon inhabiting a deep-sea hydrothermal system in the Mid-Atlantic Ridge. In line with those properties, comparison of the 16S rRNA gene places the strain in a clade of the euryarchaeotic order Thermococcales, and most closely related to the genus Thermococcus. Currently, the genus Thermococcus contains 26 validly published species, which are separated into two major clades represented by T. celer and T. litoralis, and two independent lineages of T. barophilus and T. atlanticus. The separation of the two major clades is also supported by DNA base composition. Strain OGL-20 $\mathrm{P}^{\mathrm{T}}$ is included in the clade represented by the type species of the genus T. celer. Comparison of strain OGL-20 $\mathrm{P}^{\mathrm{T}}$ with its closest neighbours on the phylogenetic tree showed a $16 \mathrm{~S}$ rRNA sequence difference of less than $1 \%$; however, DNA-DNA hybridization showed less than $20 \%$ similarity. Phenotypic and genotypic differences between strain OGL-20 $\mathrm{P}^{\mathrm{T}}$ and the closest species are shown in Table 1.

On the basis of comparative morphological, physiological and genomic data, we conclude that strain OGL-20P ${ }^{\mathrm{T}}$ 
Table 1. Comparison of characters of strain OGL-2OP ${ }^{\top}$ and its phylogenetically closest species

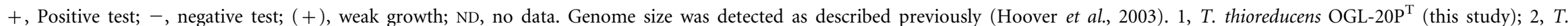

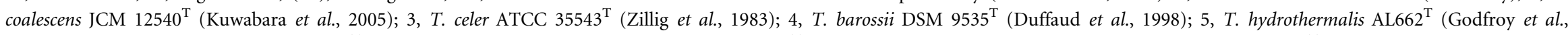

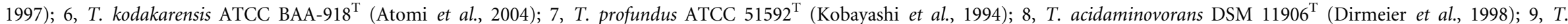
stetteri DSM 5262 ${ }^{\mathrm{T}}$ (Miroshnichenko et al., 1989); 10, T. peptonophilus ATCC $700098^{\mathrm{T}}$ (González et al., 1995); 11, T. gorgonarius ATCC 700654 ${ }^{\mathrm{T}}$ (Miroshnichenko et al., 1998).

\begin{tabular}{|c|c|c|c|c|c|c|c|c|c|c|c|}
\hline Character & 1 & 2 & 3 & 4 & 5 & 6 & 7 & 8 & 9 & 10 & 11 \\
\hline $\mathrm{G}+\mathrm{C}$ content $(\mathrm{mol} \%)$ & 52.9 & 53.9 & 56.6 & 60.0 & 58.0 & 52 & 52.5 & 49 & 50 & 52 & 50.6 \\
\hline Motility/flagellation & $\begin{array}{c}\text { Motile/ } \\
\text { monotrichous }\end{array}$ & $\begin{array}{l}\text { Motile/tuft } \\
\text { of flagella }\end{array}$ & $\begin{array}{l}\text { Motile/polar } \\
\text { polytrichous }\end{array}$ & Non-motile & $\begin{array}{c}\text { Motile/ } \\
\text { monotrichous }\end{array}$ & $\begin{array}{c}\text { Motile/polar } \\
\text { tuft of } \\
\text { flagella }\end{array}$ & $\begin{array}{l}\text { Motile/ } \\
\text { polar tuft } \\
\text { of flagella }\end{array}$ & $\begin{array}{l}\text { Motile/tuft } \\
\text { of flagella }\end{array}$ & Non-motile & Motile & $\begin{array}{c}\text { Motile/polar } \\
\text { flagella }\end{array}$ \\
\hline$S^{0}$ requirement & Obligate & $-\S$ & Facultative & Obligate & Facultative & Facultative & Obligate & Facultative & Obligate & Facultative & Obligate \\
\hline Optimum pH (range) & $7.0(5.0-8.5)$ & $6.5(5.2-8.7)$ & 5.8 & $6.5-7.5(3-9)$ & 6.0 & $6.5(5-9)$ & $4.5-8.5$ & $9.0(5.0-9.5)$ & $6.5(5.7-7.2)$ & $6(4-8)$ & $\begin{array}{c}6.5-7.2 \\
(5.8-8.5)\end{array}$ \\
\hline Optimum $\mathrm{NaCl}, \%$ (range) & $3.0(1.0-5.0)$ & $2.5(1.5-4.5)$ & $3.8-4.0(1-4)$ & $2.0(1.0-4.0)$ & $2-3$ & $3(1-5)$ & $2-4(1-6)$ & $2-3(1-6)$ & $2.5(1-4)$ & $3(1-5)$ & $2.0-3.5(1-5)$ \\
\hline Optimum $T,{ }^{\circ} \mathrm{C}$ (range) & $83-85(55-95)$ & $87(57-90)$ & $88(50-94)$ & $82.5(60-94)$ & $85(55-100)$ & $85(60-100)$ & $80(50-90)$ & $85(56-93)$ & $76(55-94)$ & $\begin{array}{c}85-90 \\
(60-100)\end{array}$ & $\begin{array}{c}80-88 \\
(68-95)\end{array}$ \\
\hline \multicolumn{12}{|l|}{ Substrates ${ }^{\star}$} \\
\hline Proteolysis products $\dagger$ & + & + & + & + & + & + & + & + & + & + & + \\
\hline Starch & - & - & ND & ND & - & + & + & - & + & $\mathrm{ND}$ & - \\
\hline Pyruvate & - & ND & $\mathrm{ND}$ & ND & $(+)$ & + & + & ND & $\mathrm{ND}$ & - & $(+)$ \\
\hline \multicolumn{12}{|l|}{ End products } \\
\hline $\mathrm{H}_{2}$ & + & $\mathrm{ND}$ & + & + & + & + & + & ND & ND & - & + \\
\hline $\mathrm{CO}$ & + & ND & - & + & - & ND & + & $\mathrm{ND}$ & $\mathrm{ND}$ & + & + \\
\hline $\mathrm{CO}_{2}$ & + & ND & + & + & + & ND & + & + & + & + & + \\
\hline Acetate & + & ND & ND & ND & + & ND & ND & ND & + & ND & + \\
\hline Lactate & - & ND & ND & ND & + & ND & ND & $\mathrm{ND}$ & ND & ND & ND \\
\hline iso-Butyrate & - & ND & $\mathrm{ND}$ & ND & + & ND & ND & ND & + & ND & + \\
\hline Propionate & - & ND & ND & ND & $-\ddagger$ & ND & ND & ND & - & ND & + \\
\hline Methylpropionate & - & ND & ND & ND & + & ND & ND & ND & - & ND & - \\
\hline iso-Valerate & - & ND & ND & ND & - & ND & ND & $\mathrm{ND}$ & + & ND & + \\
\hline$t_{\mathrm{D}}, \min$ & 30 & $\mathrm{ND}$ & 50 & 33 & 90 & ND & 50 & 120 & 72 & 25 & $\mathrm{ND}$ \\
\hline Genome size, Da & $1.23 \times 10^{9}$ & ND & $1.24 \times 10^{9}$ & $1.18 \times 10^{9}$ & $\mathrm{ND}$ & ND & $\mathrm{ND}$ & $\mathrm{ND}$ & $\mathrm{ND}$ & $\mathrm{ND}$ & $\mathrm{ND}$ \\
\hline Rifampicin resistance & - & - & + & - & + & ND & - & ND & - & - & - \\
\hline
\end{tabular}

${ }^{\star}$ All strains hydrolize casein, but not chitin.

$\dagger$ Hydrolysed proteins or peptides (peptone, yeast extract, meat extract, etc.).

†Produces 2-methylpropionate, 3-methylthiopropionate.

$\S$ Stimulatory only. 
represents a separate taxon at the species level for which the name Thermococcus thioreducens sp. nov. is proposed.

\section{Description of Thermococcus thioreducens sp. nov.}

Thermococcus thioreducens (thi.o.re.du'cens. Gr. n. thion sulfur, L. part. adj. reducens reducing, N.L. part. adj. thioreducens reducing sulfur).

Cells are irregular cocci with a diameter of $0.7-1.8 \mu \mathrm{m}$, motile by a single flagellum. Heterotrophic, strictly anaerobic. Obligately dependent upon elemental sulfur. Catalasenegative. Grows with peptone, bacto-tryptone, Casamino acids and yeast extract as electron donors, but no growth on D-glucose, fructose, maltose, sucrose, D-mannitol, glycerol, methanol, ethanol, butyrate, propionate, acetate, formate, lactate, pyruvate, citrate or amino acids. Thiosulfate, sulfite, sulfate, $\mathrm{Fe}(\mathrm{III})$ and nitrate cannot support growth as electron acceptors. Cells are hyperthermophilic, growing between 55 and $94^{\circ} \mathrm{C}$ with an optimum at $83-85^{\circ} \mathrm{C}$, and in a $\mathrm{pH}$ range of 5.0-8.5 (optimum 7.0) with an $\mathrm{NaCl}$ concentration range of $1-5 \%(\mathrm{w} / \mathrm{v})$ (optimum $3 \%)$. Doubling time is $30 \mathrm{~min}$. The main end product of growth with peptone and sulfur is $\mathrm{H}_{2} \mathrm{~S}$ (more than $20 \mathrm{mM}$ ); minor end products are $\mathrm{CO}_{2}, \mathrm{H}_{2}(0.05 \mathrm{mM})$, acetate $(2 \mathrm{mM})$ and ethanol $(3.7 \mathrm{mM})$. Sensitive to tetracycline and rifampicin. The $\mathrm{G}+\mathrm{C}$ content of the DNA is $52.9 \mathrm{~mol} \%$ (HPLC).

Type strain is strain OGL-20 $\mathrm{P}^{\mathrm{T}}\left(=\mathrm{JCM} 12859^{\mathrm{T}}=\mathrm{DSM}\right.$ $14981^{\mathrm{T}}=$ ATCC BAA-394 ${ }^{\mathrm{T}}$ ) isolated from deep-sea black smoker chimney debris in sediment mud at the Rainbow hydrothermal vent site at a depth of $2300 \mathrm{~m}$ in the Atlantic Ocean off the coast of the Azores.

\section{Acknowledgements}

We are grateful to Dr V. Kevbrin, Professor M. Farmer \& Professor J. Shields (University of Georgia, Athens, GA) for their help with measuring end products and TEM. We thank Professor Hans G. Trüper for help with nomenclature. We appreciate the assistance of Drs Anatoly Sagalevitch, Alla Lein and Nikolai Pimenov (Institute of Oceanography \& Institute of Microbiology, RAS) in sample collection. We thank Richard Garriott for partially funding the expedition. We acknowledge the NASA JSC Astrobiology Institute for Biomarkers in Astromaterials for supporting this research. Our gratitude also extends out to the University of Alabama in Huntsville Mini-Grant program for supporting extremophile research.

\section{References}

Altschul, S. F., Gish, W., Miller, W., Myers, E. W. \& Lipman, D. J. (1990). Basic local alignment search tool. J Mol Biol 215, 403-410.

Atomi, H., Fukui, T., Kanai, T., Morikawa, M. \& Imanaka, T. (2004). Description of Thermococcus kodakaraensis sp. nov., a well studied hyperthermophilic archaeon previously reported as Pyrococcus sp. KOD1. Archaea 1, 263-267.

Canganella, F., Jones, W. J., Gambacorta, A. \& Antranikian, G. (1998). Thermococcus guaymasensis sp. nov. and Thermococcus aggregans sp. nov., two novel thermophilic archaea isolated from the Guaymas Basin hydrothermal vent site. Int J Syst Bacteriol 48, 1181-1185.
Charlou, J. L., Donval, J. P., Baptiste, P. J. \& Holm, N. G. (2002). Geochemistry of high $\mathrm{H}_{2}$ and $\mathrm{CH}_{4}$ vent fluids issuing from ultramafic rocks at the Rainbow hydrothermal field $\left(36^{\circ} 14 \mathrm{~N}\right.$, MAR). Chem Geol 191, 345-359.

Dirmeier, R., Keller, M., Hafenbradl, D., Braun, F. J., Rachel, R., Burggraf, S. \& Stetter, K. O. (1998). Thermococcus acidaminovorans sp. nov., a new hyperthermophilic alkaliphilic archaeon growing on amino acids. Extremophiles 2, 109-114.

Duffaud, G. D., d'Hennezel, O. B., Peek, A. S., Reysenbach, A.-L. \& Kelly, R. M. (1998). Isolation and characterization of Thermococcus barossii, sp. nov., a hyperthermophilic Archaeon isolated from a hydrothermal vent flange formation. Syst Appl Microbiol 21, 40-49.

Godfroy, A., Meunier, J.-R., Guézennec, J., Lesongeur, F., Raguénès, G., Rimbault, A. \& Barbier, G. (1996). Thermococcus fumicolans sp. nov., a new hyperthermophilic archaeon isolated from a deep-sea hydrothermal vent in the North Fiji Basin. Int J Syst Bacteriol 46, 1113-1119.

Godfroy, A., Lesongeur, F., Raguénès, G., Quérellou, J., Antoine, E., Meunier, J.-R., Guézennec, J. \& Barbier, G. (1997). Thermococcus hydrothermalis sp. nov., a new hyperthermophilic archaeon isolated from a deep-sea hydrothermal vent. Int J Syst Bacteriol 47, 622-626.

González, J. M., Kato, C. \& Horikoshi, K. (1995). Thermococcus peptonophilus sp. nov., a fast-growing, extremely thermophilic archaebacterium isolated from deep-sea hydrothermal vents. Arch Microbiol 164, 159-164.

González, J. M., Sheckells, D., Viebahn, M., Krupatkina, D., Borges, K. M. \& Robb, F. T. (1999). Thermococcus waiotapuensis sp. nov., an extremely thermophilic archaeon isolated from a freshwater hot spring. Arch Microbiol 172, 95-101.

Grote, R., Li, L., Tamaoka, J., Kato, C., Horikoshi, K. \& Antranikian, G. (1999). Thermococcus siculi sp. nov., a novel hyperthermophilic archaeon isolated from a deep-sea hydrothermal vent at the midOkinawa trough. Extremophiles 3, 55-62.

Hoover, R. B., Pikuta, E. V., Bej, A. K., Marsic, D., Whitman, W. B., Tang, J. \& Krader, P. (2003). Spirochaeta americana sp. nov., a new haloalkaliphilic, obligately anaerobic spirochaete isolated from soda Mono Lake in California. Int J Syst Evol Microbiol 53, 815-821.

Huber, R., Stöhr, J., Hohenhaus, S., Rachel, R., Burggraf, S., Jannasch, H. W. \& Stetter, K. O. (1995). Thermococcus chitonophagus sp. nov., a novel, chitin-degrading, hyperthermophilic archaeum from a deep-sea hydrothermal vent environment. Arch Microbiol 164, 255-264.

Jolivet, E., l'Haridon, S., Corre, E., Forterre, P. \& Prieur, D. (2003). Thermococcus gammatolerans sp. nov., a hyperthermophilic archaeon from deep-sea hydrothermal vent that resists ionizing radiation. Int J Syst Evol Microbiol 53, 847-851.

Jukes, T. H. \& Cantor, C. R. (1969). Evolution of protein molecules. In Mammalian Protein Metabolism, pp. 21-132. Edited by H. N. Munro. New York: Academic Press.

Keller, M., Braun, F.-J., Dirmeier, R., Hafenbradl, D., Burggraf, S., Rachel, R. \& Stetter, K. O. (1995). Thermococcus alcaliphilus sp.nov., a new hyperthermophilic archaeum growing on polysulfide at alkaline pH. Arch Microbiol 164, 390-395.

Kobayashi, T., Kwak, Y. S., Akiba, T., Kudo, T. \& Horikoshi, K. (1994). Thermococcus profundus sp. nov., a new hyperthermophilic archaeon isolated from a deep-sea hydrothermal vent. Syst Appl Microbiol 17, 232-236.

Kumar, S., Tamura, K. \& Nei, M. (2004). MEGA3: Integrated software for molecular evolutionary genetics analysis and sequence alignment. Brief Bioinform 5, 150-163.

Kuwabara, T., Minaba, M., Iwayama, Y., Inouye, I., Nakashima, M., Marumo, K., Maruyama, A., Sugai, A., Itoh, T. \& other authors 
(2005). Thermococcus coalescens sp. nov., a cell-fusing hyperthermophilic archaeon from Suiyo Seamount. Int J Syst Evol Microbiol 55, 2507-2514.

Lovley, D. R. \& Phillips, E. J. P. (1986). Organic matter mineralization with reduction of ferric iron in anaerobic sediments. Appl Environ Microbiol 51, 683-689.

Marteinsson, V. T., Birrien, J.-L., Reysenbach, A.-L., Vernet, M., Marie, D., Gambacorta, A., Messner, P., Sleytr, U. B. \& Prieur, D. (1999). Thermococcus barophilus sp. nov., a new barophilic and hyperthermophilic archaeon isolated under hydrostatic pressure from a deep-sea hydrothermal vent. Int J Syst Bacteriol 49, 351-359.

Mesbah, M., Premachandran, U. \& Whitman, W. B. (1989). Precise measurement of the $\mathrm{G}+\mathrm{C}$ content of deoxyribonucleic acid by highperformance liquid chromatography. Int J Syst Bacteriol 39, 159-167.

Miroshnichenko, M. L., Bonch-Osmolovskaya, E. A., Neuner, A., Kostrikina, N. A., Chernyh, N. A. \& Alekseev, V. A. (1989). Thermococcus stetteri sp. nov., a new extremely thermophilic marine sulfurmetabolizing archaebacterium. Appl Microbiol 12, 257-262.

Miroshnichenko, M. L., Gongadze, G. M., Rainey, F. A., Kostyukova, A. S., Lysenko, A. M., Chernyh, N. A. \& Bonch-Osmolovskaya, E. A. (1998). Thermococcus gorgonarius sp. nov. and Thermococcus pacificus sp. nov.: heterotrophic extremely thermophilic archaea from New Zealand submarine hot vents. Int J Syst Bacteriol 48, 23-29.

Miroshnichenko, M. L., Hippe, H., Stackebrandt, E., Kostrikina, N. A., Chernyh, N. A., Jeanthon, C., Nazina, T. N., Belyaev, S. S. \& BonchOsmolovskaya, E. A. (2001). Isolation and characterization of Thermococcus sibiricus sp. nov. from a Western Siberia hightemperature oil reservoir. Extremophiles 5, 85-91.

Neuner, A., Jannasch, H. W., Belkin, S. \& Stetter, K. O. (1990). Thermococcus litoralis sp. nov.: a new species of extremely thermophilic marine archaebacteria. Arch Microbiol 153, 205-207.

Pikuta, E. V., Lysenko, A. M., Suzina, N., Osipov, G. A., Kuznetsov, B., Tourova, T., Akimenko, V. K. \& Laurinavichus, K. S. (2000). Desulfotomaculum alkaliphilum sp. nov., a new alkaliphilic, moderately thermophilic, sulfate-reducing bacterium. Int J Syst Evol Microbiol 50, 25-33.

Pikuta, E. V., Hoover, R. B., Bej, A. K., Marsic, D., Detkova, E. N., Whitman, W. B. \& Krader, P. (2003). Tindallia californiensis sp. nov., a new anaerobic, haloalkaliphilic, spore-forming acetogen isolated from Mono Lake in California. Extremophiles 7, 327-334.

Pikuta, E. V., Itoh, T., Krader, P., Tang, J., Whitman, W. B. \& Hoover, R. B. (2006). Anaerovirgula multivorans gen. nov., sp. nov., a novel spore-forming, alkaliphilic anaerobe isolated from Owens Lake, California. Int J Syst Evol Microbiol 56, 2623-2629.

Ronimus, R. S., Reysenbach, A.-L., Musgrave, D. R. \& Morgan, H. W. (1997). The phylogenetic position of the Thermococcus isolate AN1 based on $16 \mathrm{~S}$ rRNA gene sequence analysis: a proposal that AN1 represents a new species, Thermococcus zilligii sp. nov. Arch Microbiol 168, 245-248.

Saitou, N. \& Nei, M. (1987). The neighbor-joining method: a new method for reconstructing phylogenetic trees. Mol Biol Evol 4, 406-425.

Sambrook, J., Fritch, E. F. \& Maniatis, T. (1989). Molecular Cloning: A Laboratory Manual, 2nd edn. Cold Spring Harbor, NY: Cold Spring Harbor Laboratory.

Slobodkin, A. I., Jeanthon, C., L'Haridon, S., Nazina, T., Miroshnichenko, M. \& Bonch-Osmolovskaya, E. (1999). Dissimilatory reduction of $\mathrm{Fe}(\mathrm{III})$ by thermophilic bacteria and archaea in deep subsurface petroleum reservoirs of Western Siberia. Curr Microbiol 39, 99-102.

Smibert, R. M. \& Krieg, N. R. (1994). Phenotypic characterization. In Methods for General and Molecular Microbiology, pp. 611-654. Edited by R. G. Gerhardt, E. Murray, W. A. Wood \& N. R. Krieg. Washington, DC: American Society for Microbiology:

Stetter, K. O., Huber, R., Blochl, E., Kurr, M., Eden, R. D., Fielder, M., Cash, H. \& Vance, I. (1993). Hyperthermophilic archaea are thriving in deep North Sea and Alaskan oil reservoirs. Nature 365, 743-745.

Takahata, Y., Nishijima, M., Hoaki, T. \& Maruyama, T. (2000). Distribution and physiological characteristics of hyperthermophiles in the kubiki oil reservoir in Niigata, Japan. Appl Environ Microbiol 66, 73-79.

Thompson, J. D., Higgins, D. G. \& Gibson, T. J. (1994). CLUSTAL W: improving the sensitivity of progressive multiple sequence alignment through sequence weighting, position-specific gap penalties and weight matrix choice. Nucleic Acids Res 22, 4673-4680.

Trüper, H. G. \& Schlegel, H. G. (1964). Sulfur metabolism in Thiorhodaceae: I. quantitative measurements on growing cells of Chromatium okenii. Antonie Van Leeuwenhoek 30, 225-238.

Wolin, E. A., Wolin, M. J. \& Wolfe, R. S. (1963). Formation of methane by bacterial extracts. J Biol Chem 238, 2882-2886.

Zillig, W. (1992). The order Thermococcales. In The Prokaryotes, 2nd edn, vol. 1, pp. 702-706. Edited by A. Balows, H. Trüper, M. Dworkin, W. Hander \& K. H. Schleifer. New York: Springer-Verlag Inc.

Zillig, W. \& Reysenbach, A.-L. (2002). Class IV. Thermococci class nov. In Bergey's Manual of Systematic Bacteriology, 2nd edn, vol. 1. pp. 342-346. Edited by D. R. Boone \& R. W. Castenholz: New York: Springer.

Zillig, W., Holz, I., Janekovic, D., Schäfer, W. \& Reiter, W. D. (1983). The Archebacterium Thermococcus celer represents, a novel genus within the thermophilic branch of the archaebacteria. Syst Appl Microbiol 4, 88-94. 